\title{
Stylistic Analysis of Maya Angelou's “Woman Work”
}

\author{
Arina Isti'anah \\ Universitas Sanata Dharma \\ arina@usd.ac.id \\ Caecilia Riris Krismarini \\ Universitas Sanata Dharma \\ caeciliaririsk34@gmail.com \\ Elisabet Ayu Pramesthi Lebdo Putri \\ Universitas Sanata Dharma \\ elisabetayuplp@gmail.com
}

\begin{abstract}
This paper presented the stylistic analysis of a poem by Maya Angelou, "Woman Work". This stylistic analysis focused on analyzing two language levels, phonology and syntax, covering the study of sound repetition, transitivity, and pronoun. The phonological features employed in the poem were assonance and consonance. On the other hand, the syntactic features were in the form of material processes that described the works of a woman. The employment of pronoun referred to the poet and nature. This analysis found that Angelou positioned nature as an essential part of a woman's life as it helped her to provide a living to her family. Further, nature was placed as an Actor that helped her face her world as a woman. This paper concludes that stylistics is applicable to analyse literary works in an objective way as it provides the hard data.
\end{abstract}

Keywords: stylistics, poem, woman, Angelou

\section{INTRODUCTION}

Literary texts are often attached to their being aesthetic. The beauty of their language is one of the interests done by scholars. 
However, literary texts are not merely about their beauty of language but also how the choice of language creates meanings. Literary texts are made for particular purposes in particular contexts. Maya Angelou is assumed as one of the writers that use language to voice her oppression that she experienced both as a Black and a woman. The study on her works motivates the present research. Maya Angelou is an AmericanAfrican poet who experienced discrimination and oppression as black and woman in America. Through writing, Angelou also voices about the love and happiness that she feels. Her hardworking sends her as a famous writer and activist. "Woman Work" is one of her poems that reflects her life experience.

"Woman work" is not the only poem analyzed by scholars. From the literary point of view, the poem was criticized from the diction of nature chosen by Angelou. Through personification and apostrophe, nature is presented the object of escapism. Nature gives women the strength to face her world as one who has to finish house chores (Yustisiana, 2018).

Using the feminist stylistic approach, Hama (2017) analyzed the poem based on its stylistic devices to uncover how Angelou uses language to defy the problems that women face and how she presents her own identity. The use of punctuation marks, figures of speech, and nature-related terms show that Angelou does not complain about her endless chores as she is aware that it is the duty of a mother and a wife. She is mad at human beings for not valuing a woman's sacrifices to secure a comfortable life for others. Angelou, who is lonely because no one acknowledges her hard work, is thankful for nature as "they are all she has". In the end, it is concluded that Angelou is proud of being a woman and does not feel inferior to men even though it is not easy to be one (Hama, 2017).

Khan \& Khan (2016) also conducted the stylistic analysis in "Woman Work". They assessed the phonological pattern, figures of speech, and lexical devices used by Angelou in the poem. From the stylistic analysis, they mentioned the themes found in the poem that talks about black woman and slavery. The research describes how the woman enjoys her life shown from the employment of natural images in the poem (Khan \& Khan, 2016).

Triggered by the studies mentioned above, the present research attempts to improve the previous findings. Since the employment of some phonological and syntactic elements is still missing in the earlier studies, this paper provides alternative ways on how to interpret the poem. This paper also develops research on stylistics, particularly 
literary works by Maya Angelou. Therefore, this research focuses on how the syntactic and phonological features help readers interpret the poem. There are two research questions discussed in this research: how are phonological and syntactic features employed in the poem and what the employed linguistic features depict interpretation.

\section{THEORETICAL FRAMEWORK}

The concept of style is often related to physical things such as buildings and fashion. In terms of language, style is often attached to the author, like Hemmingway's style and Dicken's style referring to the complexity of language and theme in the works. However, 'style' is the linguistic characteristics of a particular text (Leech \& Short, 2007). It means that the study of style should rely on particular text since to find out the generalization of an author's language is not a simple job.

Stylistics is a linguistic field that presents an approach and method to analyze the purpose and function of a text, not restricted to literary but also non-literary texts. Poetry, one of literary works, does not "make direct reference to the world of phenomena but provides a representation of it through its peculiar and unconventional uses of language" which create an imaginary alternative world (Verdonk, 2002). Thus, critical analysis of the employed language in poetry becomes necessary to conduct.

In conducting stylistics, there are some levels of language to observe: semantic, syntactic, graphological, and phonological levels (Leech \& Short, 2007). The chart below displays the relation between language levels and the message of a literary work.

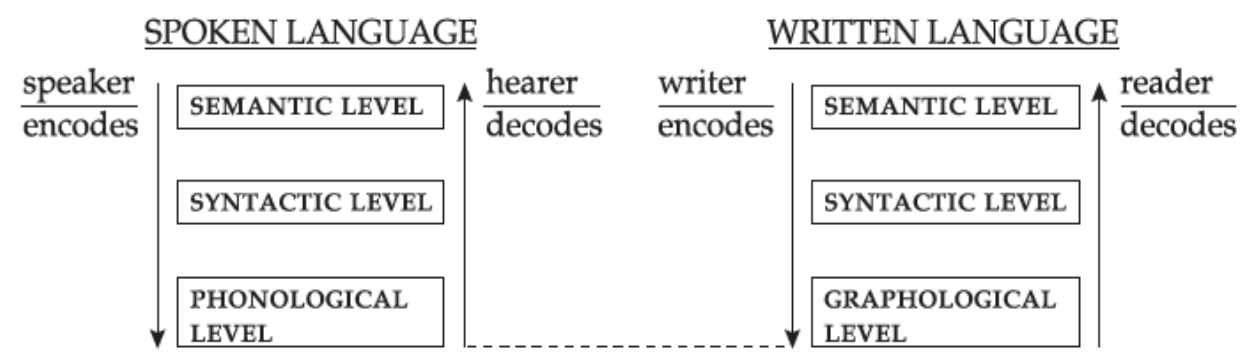

The above chart reveals that to interpret a literary work, the role of a reader's knowledge also becomes central. The model reality in the above chart refers to things that "we know, believe, judge or understand to be the case in the world that we live" (Leech \& Short, 2007). The job for stylisticians is to provide hard data, or linguistic evidence, to support 
our judgment of a particular text. In other words, careful analysis of linguistic choice needs to be elaborated and presented.

The language levels employed in this paper are phonological and syntactic. In the phonological level, the analysis is focused on the employment of assonance and consonance. Assonance and consonance are regarded as a deviation in poetry. Assonance is the repetition of the vowel sound in two or more words in a line of a poem, whereas consonance is the repletion of consonant sound in two or more words in a line of a poem (Hameed \& Al-Sa'doon, 2015). Instead of assonance and consonance, a poem can involve alliteration, the repletion of consonant sound at the beginning of two or more words in a line. However, the discussion of alliteration is not involved here since it has been previously conducted by another scholar.

In the syntactic level, this paper is interested in discussing the use of pronoun and transitivity. From a systemic functional linguistic point of view, meanings are represented through what so-called as meta-functions of language. The first function is the ideational function, referring to how language is employed to express people's experience of both the outer and inner world of their consciousness (Li \& Tao, 2018). The language element that is utilized to figure out the ideational meaning is the verb. The choice of the verb determines types of process, thus participants and circumstances. Six processes are proposed in SFL: material, mental, verbal, relational, behavioral, and existential processes.

The material process is marked by verbs of doing and happening. Usually, the verbs are dynamic. The mental process is about sensing or people's consciousness. It refers to the process of perceptive, cognitive, emotive, and desiderative (Isti'anah, 2018). The relational process is about being and having, marked by identifying, attributing or possession processes. The behavioral process is about physiological and psychological behavior. The verbal process marked by verbs of saying. The process is important in various kinds of discourse. They contribute to the creation of a narrative by making it possible to set up dialogic passages. The existential process is about the idea that something exists or happens (Yuqiong \& Li, 2018).

As the study of language style, stylistics takes account of the style and the ways language is used in texts. Stylistics examines the language features "such as rhetorical terms and syntactic devices that are used to create expressive or literary style" (Mukhtar, 2017). In addition to that stylistics can disclose the type of a text by its language features. Stylistics not only enables us to identify the distinctive features of 
literary texts but also to specify the genre and structures of literature (Budiharto, 2014).

\section{RESEARCH METHODOLOGY Approach}

This paper applied the stylistic approach. It concerns the language style, either literary or non-literary text. This paper analyzes Angelou's "Woman Work" through different language levels: assonance and consonance in the phonological level and transitivity and pronoun in the syntactic level. The detailed linguistic features of the poem are needed to analyze since stylistics aims at providing hard data to help stylisticians interpret the meanings of a literary work (Barry, 2002) 2002).

\section{The procedure of Data Collection and Data Analysis}

The data focused on this paper were taken from phonological and syntactic features. The phonological features focus on the repetitions of sounds from every line. The researchers paid attention to the employment of vowels and consonants repeated in each line. The use of the Longman Dictionary helped the researchers transcribe the sounds. In the syntactic features, the choice of verbs was categorized into its transitivity process since it was the marker whether a clause was a material, relational, verbal, or other types of processes. The last syntactic feature analyzed was the use of the pronoun. It helped the researchers interpret the significance of the pronoun in the poem. The employed linguistic features mentioned lead the poem interpretation.

\section{FINDINGS}

This part displays the results of the analysis. As there were two language levels observed, the results were divided into their language levels as below.

\section{Phonological Level}

In this level, two types of sound repetition were analyzed: assonance and consonance. Assonance is the repetition of the similar sound of the vowel in a line that can be in the initial, middle, or at the final position of words. The table below shows a summary of the phonological features found in the novel.

Table 1. Summary of Phonological Features in "Woman Work"

\begin{tabular}{|l|l|l|l|}
\hline Phonological & Sounds & Stanza, Line & Words \\
\hline
\end{tabular}




\begin{tabular}{|c|c|c|c|}
\hline \multicolumn{4}{|l|}{ Features } \\
\hline \multirow[t]{9}{*}{ Assonance } & /ə/ & $\begin{array}{l}1 \text {, lines } 1,8,13 \text {, } \\
14\end{array}$ & $\begin{array}{l}\text { the, children, garden, } \\
\text { about, cotton }\end{array}$ \\
\hline & /i/ & 1, line 7 & company, feed \\
\hline & $/ \Lambda /$ & 1 , line 12 & up, hut \\
\hline & /aI/ & 2, line 1 & shine, sunshine \\
\hline & /eI/ & 2 , line 2 & rain \\
\hline & $/ \mathrm{I} /$ & 3 , line 2 & $\begin{array}{l}\text { with, fiercest, and } \\
\text { wind }\end{array}$ \\
\hline & /e/ & 4 , line 4 & let, rest \\
\hline & /ov/ & 5, line 2 & ocean, stone \\
\hline & /aI/ & 5 , line 5 & $I, m y$ \\
\hline \multirow[t]{22}{*}{ Consonance } & /d/ & 1 , line 1 & children, tend \\
\hline & $/ \mathrm{t} /$ & 1, line 1 & got, to \\
\hline & /ð/ & 1 , line 2 & the, clothes \\
\hline & $/ \mathrm{n} /$ & 1, line 5 & then, chicken \\
\hline & $/ \mathrm{t} /$ & 1 , line 7 & got, to \\
\hline & $/ \mathrm{d} /$ & 1, line 8 & garden, weed \\
\hline & $/ \mathrm{s} /$ & 1, line 9 & shirts, press \\
\hline & $/ \mathrm{s} /$ & 1, line 10 & tots, dress \\
\hline & $/ \mathrm{t} /$ & 1 , line 11 & to, cut \\
\hline & $/ \mathrm{J} /$ & 2, line 15 & shine, sunshine \\
\hline & $/ \mathrm{f} /, / \mathrm{l} /$ & 2, line 17 & fall, softly \\
\hline & $/ \mathrm{m} /, / \mathrm{r} /$ & 3, line 19 & storm, me, from, here \\
\hline & $/ \mathrm{r} /$ & 3 , line 20 & your, fiercest \\
\hline & $/ \mathrm{k} /$ & 3, line 21 & across, sky \\
\hline & $/ \mathrm{f} /, / \mathrm{l} /$ & 4 , line 23 & $\begin{array}{l}\text { fall, } \\
\text { snowflakes }\end{array}$ \\
\hline & $/ \mathrm{d} /$ & 4 , line 25 & cold, and \\
\hline & $/ \mathrm{t} /$ & 4, line 26 & let, rest, tonight \\
\hline & $/ \mathrm{n} /$ & 5 , line 27 & sun, rain \\
\hline & $/ \mathrm{r} /$ & 5, line 27 & rain, curving \\
\hline & $/ \mathrm{k} /$ & 5 , line 27 & curving, sky \\
\hline & $/ \mathrm{l} /$ & 5, line 30 & all, call \\
\hline & $/ \mathrm{n} /$ & 5 , line 30 & can, own \\
\hline
\end{tabular}

\section{Syntactic Level}

The analysis of syntactic level applied transitivity analysis by Halliday's Systemic Functional Linguistics. Transitivity is the language tool to represent the speaker's experience of the real world. The 
analysis starts with the choice of a verb that determines the type of process, thus participants and circumstances. The table below summarizes the transitivity patterns found in the poem.

Table 2. Summary of Transitivity Processes in "Woman Work"

\begin{tabular}{|l|l|l|}
\hline \multicolumn{1}{|c|}{ Processes } & \multicolumn{1}{c|}{ Participants } & \multicolumn{1}{c|}{ Verbs } \\
\hline Material & Actor - Goal & got \\
\hline Material & Goal & $\begin{array}{l}\text { shine, fall, rain, cool , } \\
\text { blow, float, cover, } \\
\text { glow }\end{array}$ \\
\hline Material & Actor & rest \\
\hline Relational & Carrier - Attribute & are \\
\hline
\end{tabular}

Additionally, this paper observed textual function of language, how a message is signposted, through pronoun used. The table below displays a summary of the pronoun used.

\begin{tabular}{|c|c|c|}
\hline Pronoun & Frequency & Stanza, line \\
\hline I & 6 & $\begin{array}{l}1, \text { lines } 1,7,9 \text {, } \\
12 \\
3 \text {, line } 4 \\
5, \text { line } 4\end{array}$ \\
\hline $\mathrm{Me}$ & 6 & $\begin{array}{l}2 \text {, lines } 1,2 \\
3 \text {, lines } 1,3 \\
4, \text { lines } 2,4\end{array}$ \\
\hline My & 2 & $\begin{array}{l}3 \text {, line } 4 \\
5, \text { line } 4\end{array}$ \\
\hline Your & 1 & 3, line 2 \\
\hline You & 1 & 5, line 4 \\
\hline Total & 16 & \\
\hline
\end{tabular}

The table above shows that there are 16 pronouns employed by Angelou in her poem. The presence of $I$ and me occupy the same number in the poem, which exists 6 times. The other pronouns are my that exists twice and your and you that only exists once.

\section{DISCUSSION}

In "Woman Work" Angelou attempts at emphasizing the things she has to take care. It is not only about chores, but her responsibility as a woman working at home to make sure that her family deserves her 
best effort. The emphasis on them is utilized through assonance and consonance, as presented in stanza 1 below.

I've got the children to tend

The garden to weed

Then see about the sick

And the cotton to pick. line 1

line 8

line 13

line 14

The underlined letter above has similar consonant sound, or what so-called assonance in stylistics. In the first and second lines of stanza 1, Angelou emphasizes that she has to take care of not only children but also the garden. The comparison between human and nonhuman beings in both lines put children and garden the same importance to her. It is not only the human beings to be responsible for but also the non-human beings that become important for her life.

The importance of non-human beings in stanza 1 is stressed by the employment of the same alveolar nasal consonant $/ \mathrm{n} /$ in line 14 , presented by the noun cotton. The repetition of $/ \mathrm{n} /$ in words children, garden, and cotton is not only to make the poem easy listening, but it has a particular purpose. Angelou regards the garden as a source of living. The presence of garden is not a place to escape, yet it provides living for her family.

In the above stanza, the clause is presented in the form of material process, referring to the speaker's way to construe the material world that is represented by the involvement of Actor and Goal as the participants (Cunanan, 2011). The Actor mentioned in stanza 1 is $I$ referring to Angelou as the speaker. The verbs employed to show her experience and doing are modals got and main verbs tend, feed, press, and hut. The Goals involved are children company, shirts, and this hut.

In stanza 1, Angelou represents herself as a woman and mother who completes her tasks. An Actor is the participant that uses energy to complete the actions directed to the Goal. Seen from stanza 1, the Goals involved refer to both human beings and non-human beings. Lines 2 until 8 contain verb phrases, which has the same function as children and to tend in line 1, which is as a Goal and Circumstance of purpose.

The clothes to mend

The floor to mop

The food to shop

Then the chicken to fry

The baby to dry

The garden to weed

The tots to dress

The can to be cut line 2

line 3

line 4

line 5

line 6

line 8

line 10

line 11 
In stanza 1 above, Angelou expresses Goals and Circumstances of purpose which have been done by the Actor, woman. It signifies that a woman has tough jobs done every day. The jobs are domesticated actions related to a family's living. The Goals above are to mend, to mop, to shop, to fry, to weed, to dress, to be cut, and to pick. Those purposes seem to be never-ending tasks done by the Actor. The presence of Circumstances in almost every line in stanza 1 reveals how strong a woman is. The jobs a woman are done over and over continuously, are presented in the long stanza above.

What is interesting here is the Actor that is only present once, yet the Goals and Circumstances of purpose are always present in almost every line. Here, Angelou emphasizes that her presence as a woman is not necessary to involve. She does not want to be acknowledged as an important figure in the poem, yet what is more important is the Goal and purposes. In other words, family is more important than her. She wants to make sure that her family is well-taken care of regardless of the acknowledgment given by other people.

Stanza 2 employs nature-related terms. The repetition of vowels and consonants in the lines that contain nature-related terms emphasize how important nature is for Angelou. In stanza 2, assonance is found in line 1 and 2 represented as follow.

Shine on me, sunshine $\quad$ stanza 2, line 1

Rain on me, rain $\quad$ stanza 2, line 2

Fall softly, dewdrops $\quad$ stanza 2, line 3

In those lines, the assonances are in the form of a diphthong. In line 1, the repetition of assonance /ar/ occurs in words shine and sunshine. In line 2 the repetition of sound /eI/ occurs in the same words rain. Meanwhile, in line 3 of stanza 2 the repetition of vowel / $/$ occurs in words fall and softly. Assonances show the way Angelou begs nature hto comfort her: sun to shine on her, rain to rain on her, and dewdrops to fall softly on her.

In stanza 2, consonance is found in line 1 and 3 . In line 1 , the consonant $/ \mathrm{J} /$ is repeated in shine and sunshine. In line 3 , the consonant /f/ and /l/ are repeated in fall and softly.

Shine on me, sunshine stanza 2, line 1

Fall softly, dewdrops $\quad$ stanza 2, line 3

The same as the assonances, consonances in line 1 and 3 above also highlight the importance of nature for Angelou. Nature is present as 
an important being who provides comfort for Angelou after her long day of endless works as a woman.

Such meaning is also conveyed by the appearance of material process and the use of pronoun in stanza 2 .

Shine on me, sunshine $\quad$ stanza 2, line 1

Rain on me, rain $\quad$ stanza 2, line 2

Fall softly, dewdrops $\quad$ stanza 2, line 3

And cool my brow again stanza 2, line 4

In line 1, the Agent is sunshine and the material verb is shine. In line 2, both Agent and the material verb are rain. Me becomes the Goal in line 1 and 2. In line 3, the Agent is dewdrops, while fall performs as the material verb. In line 4, the Agent is the same as that in line 3 , which is dewdrops, cool is the material verb and my brow is the goal.

The presences of nature-related terms, such as sunshine, rain, and dewdrops, as the Agents in stanza 2 reveal that nature has the power to direct actions to Angelou, a woman, and a mother. The placement of material verbs in lines 1 to 4 above emphasizes the actions nature does to Angelou. Here, Angelou attempts at focusing on the power of nature, rather than herself as the Goal.

Pronoun appears thrice in stanza 2. Those are $m e$ in line 1 and 2, and $m y$ in line 4 as presented in the following.

Shine on $\underline{m e}$, sunshine stanza 2, line 1

Rain on $\underline{m e}$, rain stanza 2 , line 2

Fall softly, dewdrops stanza 2, line 3

And cool my brow again stanza 2, line 4

All the pronoun in stanza 2 above shows how Angelou places herself as the Goal. As mentioned previously, Angelou does not want to be acknowledged as an important figure in the poem. It is fine for Angelou to be seen that way, as what is important for her is to provide a living for her family. By mentioning nature-related terms and placing herself as the goal, Angelou wants to emphasize that she needs rest for a moment and the nature to comfort her during her rest before continuing her works.

In stanza 3, Angelou speaks about her struggles of being a woman work. This poem reflects the tragedy of the life of a slave that has to work hard routinely and only can find joy if the works are done (Khan \& Khan, 2016). It can be seen from the repetition of vowel and consonance sounds in the stanza. The repetition of a vowel is found in line 2 . The repetition of front close-mid vowel /I/ appears in words with, fiercest, and wind. Below is the appearance of the assonance in stanza 3.

With your fiercest wind

stanza 3, line 2 
Stanza 3 uses consonance of each line. The display of the consonance in stanza 3 is presented as follows.

Storm, blow me from here stanza 3, line 1

With your fiercest wind stanza 3 , line 2

Let me float across the sky

'Til I can rest again stanza 3, line 3 stanza 3, line 4

The bilabial nasal consonant $/ \mathrm{m} /$ and palatal liquid consonant $/ \mathrm{r} /$ are repeated in line 1 . The consonant $/ \mathrm{r} /$ is also repeated in words your and fiercest in line 2 . In line 3 , the velar stop consonance of $/ \mathrm{k} /$ is found in the words across and sky. While in line 4 , the repetition occurs in alveolar nasal consonant $/ \mathrm{n} /$ in words can and again.

The existence of assonance and consonance highlights the use of nature that draws the struggles faced by Angelou. The struggles are expressed through the presence of words storm, fiercest wind, and sky. The struggles depicted in this stanza are also emphasized by the appearance of material process and pronoun.

Storm, blow me from here stanza 3, line 1

With your fiercest wind stanza 3 , line 2

Let me float across the sky

'Til I can rest again stanza 3, line 3 stanza 3, line 4

In line 1 , the Actor is storm, and the material verb is blow. It creates an image of big struggles represented by storm blows or comes to life. Line 2 contains an instrument, fiercest wind. In line 3 , the Actor is the same as line 1 , while me performs as the Goal. The material verb float and the circumstances across the sky draw the journey of the woman work in facing the world that full of difficulties. In line 4, there is a material process, but the category is not an action, but happening as rest is an intransitive verb. This line depicts that the Actor tells to the storm to come until she can cope with all the struggles in life and find rests.

This stanza includes pronouns me, your, and $I$ as displayed below.

Storm, blow me from here

With your fiercest wind

Let me float across the sky

'Til $\underline{I}$ can rest again stanza 3, line 1

stanza 3, line 2

stanza 3 , line 3

stanza 3, line 4

The pronoun your substitutes the storm that appears in line 1 . The pronoun me in lines 1 and 3 shows that the poet or Angelou 
works as the Goal who is affected by an action. However, the pronoun $I$ line 4 has a function to show that Angelou stands as the agent. From the presence of $I$ and $m e$, she represents herself as a worker who has to finish her task with facing struggles in it, and she cannot rest completely because of the task.

In stanza 4, Angelou still mentions nature-related terms. Consonants and vowels are repeated in the lines containing naturerelated terms to highlight how important the role of nature in Angelou's life. Assonance only appears once in line 4. In this line, the repetition of vowel $/ \varepsilon /$ occurs in words let and rest shown as follow.

Let me rest tonight. stanza 4, line 4

Apart from assonance, stanza 4 also includes consonance that appears in lines 1, 3, and 4 . The consonant /f/ and /l/ are repeated in line 1 in fall, gently, and snowflakes. The consonance of /d/ is found in line 3 in cold and and. In line 4, the consonance of /t/ appears in let, rest, and tonight.

Fall gently, snowflakes

stanza 4, line 1

Cover me with white stanza 4, line 2

Cold icy kisses and

Let me rest tonight stanza 4, line 3 stanza 4, line 4

Using assonance and consonance, Angelou shows how nature is important for her. Nature exists in her life as a provider of comfort. As seen in the lines above, Angelou begs snowflakes, which is a part of nature, to comfort her by covering her and let her rest. This interpretation strengthens Hama's finding that mentions how Angelou thanks nature to help her face the difficult life as a woman (Hama, 2017). The present research improves Hana's research in the way phonological features also contribute to the significance of language to the poem interpretation. While Hama's research used figures of speech and punctuation, this research employs assonance and consonance to figure out the importance of nature in the representation of a woman work's life.

The representation of the process and the use of pronoun in stanza 4 also convey such meaning.

Fall gently, snowflakes

Cover me with white

Cold icy kisses and

Let me rest tonight.

stanza 4, line 1

stanza 4, line 2

stanza 4, line 3

stanza 4, line 4

The Actor in those four lines is the same, snowflakes. The instrument is white cold icy kisses though they are in different lines. In 
line 4, the material verb, happening, also appears with the Goal me and time tonight.

The presence of snowflakes as the Actor in stanza 4 shows that nature is a powerful being in Angelou's life, as mentioned in stanza 2 that nature has the power to direct actions to Angelou. The material verbs, such as fall, cover, and rest, exist to emphasize the actions of nature to Angelou. The same as in stanza 2, Angelou places herself as the Goal, as shown in line 2 and 4 by the word me. By placing herself as the Goal, Angelou wants to shift the focus on nature rather than herself for she does not want to be acknowledged as an important figure in the poem.

In stanza 4, the pronoun appears twice. Those are me in lines 2 and 4 as shown in the following.

Fall gently, snowflakes

stanza 4, line 1

Cover $\underline{m e}$ with white stanza 4, line 2

Cold icy kisses and stanza 4, line 3

Let $\underline{m e}$ rest tonight. stanza 4, line 4

The pronoun $m e$ in lines 2 and 4 are the representation of Angelou, who places herself as the Goal. By doing so, she wants to emphasize that she is only a receiver of comfort from nature, not an important figure at all. What important for Angelou is to provide a living for her family and in between that, she needs a rest or "an escape" for a while to seek comfort from nature.

In line with Yustisiana (2018), nature is portrayed as the object of escapism in the poem. Nature provides comfort to Angelou when she rests for a while after doing her endless chores as a woman and a wife (Yustisiana, 2018). The word tonight mentioned in line 4 indicates that Angelou only asks for a brief time to rest before continuing her chores. Thus, it is safe to say that nature is an escape for Angelou, who gives strength to face her world as a woman and a wife who have to finish her chores.

In stanza 5 , the consonant $/ \mathrm{n} /$ is repeated in lines 27 and 30 . Other than the consonance of $/ \mathrm{n} /$, the consonances of $/ \mathrm{r} /$ and $/ \mathrm{k} /$ are also spotted in line 27 . While in line 30 , the consonance of $/ \mathrm{l} /$ is spotted. Below is the appearance of consonances found in line 27 and 30.

Sun, rain, curving sky stanza 5, line 27

You're all that I can call my own stanza 5, line 30

Consonances found in stanza 2, 3, and 4 highlight the naturerelated terms. The nature-related terms are to show how nature comfort Angelou after doing her chores. As mentioned in line 30 above, 
nature is the only thing that is always there for her, the only thing that "she can call her own".

In stanza 5, there is a relational process, particularly to show possession. Here is the stanza.

Sun, rain, curving sky

Mountains, oceans, leaf and stone stanza 5, line 1

Star shine, moon glow stanza 5, line 2

You're all that I can call my own. stanza 5, line 3 stanza 5, line 4

The Possessor is in the form of a noun phrase, all that I can call my own, while the Possessed are the nouns in lines 1 to 3 . The use of this process shows that the Possessor, referring to woman, has no one to accompany her daily work but nature. The use of nature in this poem is the bridge into escapism (Yustisiana, 2018). Nature has a great effect on this poem. Nobody can limit the freedom of nature. As a worker, she cannot go anywhere and cannot feel free as an individual. Then, the woman imagines the freedom that she might have through nature. In addition to that, nature-related terms are mentioned throughout the poem from stanza 2 until 5 to show how important the role of nature in Angelou's life. Angelou is thankful for nature as "they all that she can call her own" (Hama, 2017). Nature is the only thing that accompanies and comforts Angelou during her break.

\section{CONCLUSION}

The findings of assonance deliver to specific interpretations. Firstly, through the repetition of sounds, Angelou tries to gain the readers' attention to the wording of the poem. Secondly, the assonance highlights the words connected to a mother and woman work. Thirdly, the assonance appeared in metaphors represented in the form of nature lexical terms.

This paper concludes that consonance is the prominent feature in the phonological level as it appears in every stanza in the poem. Consonance highlights the endless chores done by women in stanza 1 . In stanza 2 until 4, consonance is used to highlights nature-related terms. This paper concludes that all language levels can be applied to interpret Angelou's "Woman Work" as each level cannot be analyzed separately. The presence of the phonological level is proven to overlap the lexical level, seen from the choice of assonance and consonance in the figures of speech. The presence of the syntactic level is also an unavoidable analysis of the graphological level. 


\section{SUGGESTIONS}

For further improvement of stylistic analysis, the researcher would like to suggest other researchers conduct researches using stylistic analysis in different objects. Since Angelou discusses interesting topics in her poems, such as nature and equality, the objects can be other Angelou's poems that discuss similar topics. The objects can also be the poems by different authors, or other literary works that have not been analyzed previously. In addition to that, the researcher also suggests other researchers broaden the researches by extending the language levels. This research is done only in four language levels; thus, it is preferable for further researches to apply more language levels in analysis. By applying more language levels, a thorough result of the meaning of the poem can be achieved.

\section{REFERENCES}

Barry, P. (2002). Beginning Theory: An Introduction to Literary and Cultural Theory. Manchaster: Manchaster University Press.

Budiharto, R. A. (2014). Stylistic Value of Deixis in Some Selected Poems of Edgar Allan Poe. In 3rd ELTLT International Conference Proceedings (pp. 629-636).

Cunanan, B. T. (2011). Using Transitivity as a Framework in a Stylistic Analysis of Virginia Woolf's Old Mrs. Grey. Asian EFL Journal, 54, 69-79.

Hama, B. S. (2017). Self-Presentation in Selected Poems of Maya Angelou. International Review of Social Sciences, 5(2), 123-128.

Hameed, A. M., \& Al-Sa'doon, S. (2015). A Study of Stylistic Deviation in Maya Angelou's Still I Rise. European Academic Research, III(6), 6563-6586.

Isti'anah, A. (2018). Mental Processes of the Main Character in Jhumpa Lahiri's Interpreter of Maladies. Language Circle, 12(2), 213-226. https://doi.org/10.15294/lc.v12i2.14180

Khan, A. B., \& Khan, M. Y. (2016). Stylistic Analysis of the Poem "Woman Work" by Maya Angelou. International Journal of Institutional \& Industrial Research, 1(2), 10-14.

Leech, G., \& Short, M. (2007). Style in Fiction. Harlow: Pearson. 
Li, F., \& Tao, R. (2018). Transitivity Analysis of J. K. Rowling's Commencement Address at Harvard University. International Journal of Languages, Literature and Linguistics, 4(3), 208-225. https://doi.org/10.18178/ijlll.2018.4.3.176

Mukhtar, K. (2017). Stylistic Analysis of Ted Hughes' Poem: “The Casualty". Research Journal of English Language and Literature (RJELAL), 5(4), 394-401.

Verdonk, P. (2002). Stylistics. Oxford: Oxford University Press Inc.

Yuqiong, Z., \& Li, F. (2018). Transitivity Analysis of David Cameron's Speech in Retaining Scotland. International Journal of Language and Linguistics, 6(3), 70-79. https://doi.org/10.11648/j.ijll.20180603.13

Yustisiana, R. A. (2018). Elements of Nature as the Object of Escapism in Maya Angelou's "Woman Work." Journal of Language and Literature, 18(2), 158-167. 